\title{
ケーキの外観印象の共分散構造分析
}

\author{
志堂寺和則 ${ }^{\S} ，$ 都甲 潔 \\ 九州大学大学院システム情報科学研究院
}

\section{Structural Equation Modeling of Impressions of Cake Palatability Based on Appearance}

\author{
Kazunori Shidoji ${ }^{\S}$ and Kiyoshi Toko
}

Faculty of Information Science and Electrical Engineering, Kyushu University,

744 Motooka, Nishi-ku, Fukuoka 819-0395

\begin{abstract}
It is common to judge the palatability of food on the basis of its appearance. However, few studies have examined the viewer's mental process while this opinion is formed. In this study, we conducted a survey, using the SD method, of subjects' impressions of photographs of cakes to investigate how the feeling of palatability is processed. We hypothesized several basic models for the mental process based on the results of the survey, and tested each of these by structural equation modeling. The model that best fits the survey data is as follows. Impressions of both colors and structures are created when the subject views a photograph of food. Both of these have a causal relationship, and the overall impression of the photograph is a combination of these impressions. The viewer's individual taste preferences in sweets affect impressions of color but not of structure. The overall impression of the cake photograph and the viewer's individual preferences combine to yield a total assessment of the photograph, which is a determination of how delicious the cake looks.

(Received Mar. 16, 2006 ; Accepted Oct. 3, 2006)
\end{abstract}

Keywords : impressions of cake photos, appearance, structural equation modeling キーワード : ケーキ写真の印象, 外観, 共分散構造分析

食品のおいしさは人間の感覚が複合的に働いて決定され る.われわれは食品を見て，あるいは食品の写真を見て， おいしそうだとか辛そうだとかの判断を（間違っているか あしれないが）することができる，食品の外見つまり見た 目は, 味の認知と食品への満足度に対して八ロー効果を持 つことがあり,「最初の味覚はたいてい視覚から生じる」1). このため，食品を作る側は見た目にこだわり，少しでも消 費者の関心を惹こうと努力を払っている.

食品加ら連想する語を調べた研究から, テクスチャや香 りよりも外観を連想することが多いことが示されており， 色や形といった見た目は食品の品質を評価する上で重要で あるとされている22.

しかし，見た目の扔いしさに関わる科学的な研究は，実 際にはほとんど行われていないのが実状である. 食品の官 能検査では, 見た目は多数ある検査項目の中のほんの 1 な いしは 2 項目として扱われることが多く, 見た目について より詳細に分析することはない。

真柳らは，バニラカップアイスのおいしさ印象について 共分散構造分析を試みている ${ }^{3}$. その結果, 触感の好み上

干819-0395 福岡市西区元岡 744

$\S$ 連絡先 (Corresponding author), shidoji@brain.is.kyushu-u.ac.jp
りも風味の好みの方が総合的なおいしさに強く影響するこ とが明らかとなった。しかしながら,この研究においてあ, 見た目は色についてしか官能評価を抢こなって招らず，解 析途中に扔いて影響が小さいとして分析対象から外してい る。このように食品の味を全体として評価する場合, 味覚 から得られる情報と比較して視覚からの情報は弱く, 未分 析となりがちである。

相良らは，扔いしさに影響を及ぼす要因として，知覚的 要因 (味, 香り, テクスチャ, 色, 形等), 要求的要因 (甘 党, 濃い味好き, 空腹等), 認知的要因 (価格, 産地, $\mathrm{CM}$ 等)の3つを挙げている ${ }^{4)}$. 本研究では, 視覚に関する知覚 的要因と要求的要因がどのように打いしそうという感情を 引き起こすのかについて考えたい。

実験に先立ち，われわれは以下のような仮説を立てた。 前段で記したように，今回は，食品を見て生じる，おいし そうだとか食べたいといった感情は, 食品の外観が視覚情 報として目に入り生起する印象と見る人の内部要因によっ て決まるものとする。，生起する印象とは，新鮮そうだとか 甘そうだとか柔らかそうだといったもので，食品について の視覚情報自体加ら比較的直接的に惹起されるあののこと である。一方, 見る人の内部要因とは, 空腹具合や食物の 
嗜好などの要因で, 食品の外観とは無関係に見る人の内部 状態によって決まるもののことである。この内部要因は, お いしそうという感情に直接作用することも考えられるし， 印象の形成にも影響を及ぼして, 間接的に感情に作用する とも考えることができる.

本研究では, 実際においしそうという感情に関わる印象 や内部要因にはどのようなものがあるのか, そしてそれら の間にはどのような関係があるのかを詳細に検討するため に, 共分散構造分析を用いることとした。共分散構造分析 は, 真柳らも用いているが，実際に観測できる変数（アン ケートの回答結果や官能検査の結果等）や心理的な観測不 可能な構成概念間の因果関係を検証的に調べることのでき る統計手法である5)

共分散構造分析にかけるモデルを作成するために，ま ず，SD 法によるアンケート調査をおこない，食品から生 起する種々の印象, 感情がどのようにグルーピングされる かを調べた。 そして，その結果を参考に複数のモデルを立 て, 共分散構造分析により, その中から最適な説明モデル を決定した。

\section{実 験 方 法}

\section{1. 刺激材料}

刺激として 8 枚のケーキの写真 (図 1) を用いた. 実物で はなく写真を用いたのは, 香りの影響を排除するためであっ た. また, 本研究では, ケーキという一つ一つが微妙に細 部が異なる食品, 時間と共に状態が変化する食品を対象と しているため, 多数のパネルにできるだけ同じ視覚的刺激 が提供できることを考慮した結果でああった.

ケーキは福岡市内のケーキ店より購入し, 著者らがデジ タルカメラで撮影した. 解像度は $2272 \times 1704$ ピクセルで あった。ケーキを用いたのは, 見た目で判断するため, 種
類が豊富で外観の変化が大きい方が種々の印象・感情が はっきりと生じること, 嫌いな人が少ないこと, 写真に取 りやすいことなどの理由である.

\section{2. パネル}

大学生, 大学院生, 261 名.

\section{3. 手 順}

実験は 4 名以下の少人数で実施した場合と，100 名強の 大人数で実施した場合（2 組）があったが，手順は同一で あった. 少人数実施の場合は, ノート PCのモニ夕画面 (12.1インチディスプレイ, $1024 \times 768$ ピクセル) を用いて 刺激を提示し, 大人数の場合は, 200 名程度規模の教室で プロジェクタ投影をおこなった。

実験は以下の 3 つのステップで実施した.

(1) ステップ 1

パネルに 8 枚の写真を 1 枚あたり 5 秒間, 順次閲覧させ た.この手続きは, 回答する際に天井効果やフロア効果が 生じないようにするために実施した。 写真の提示順序は回 答するときと同一で，実施回毎にランダムとした。

(2) ステップ 2

パネルに写真毎に印象について回答させた。使用した形 容詞対を表 1 に示す. 形容詞対は, あらかじめ 4 名のブ レーンストーミングによりケーキ写真から想起しやすい形 容詞を検討して決定した。形容詞対を数直線の両端に配置 し「非常に」「かなり」「やや」「どちらでもない」「やや」 「かなり」「非常に」の 7 件法で回答させた。 写真の提示時 間は特に決めず，各パネルがすべて回答し終えたことを確 認して, 次の写真を見せた. 以下ではここで回答した項目 19 項目を印象項目と呼ぶ.

(3) ステップ 3

最後に，パネルに，フェイス・シート項目（年齢や性別 等), 空腹状態 (食後経過時間の記入, 空腹具合の 7 段階評

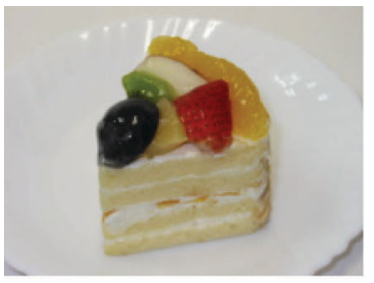

刺激 $\mathrm{A}$ 果実の森

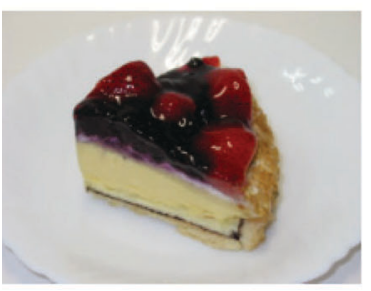

刺激 $\mathrm{E}$ ベリーベリーの レアチーズケーキ

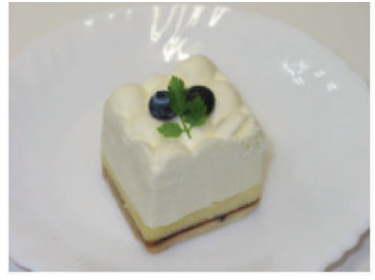

刺激 B レアチーズケーキ

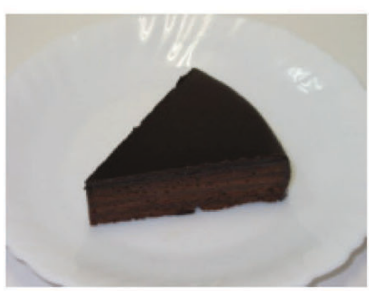

刺激 F ザッハトルテ

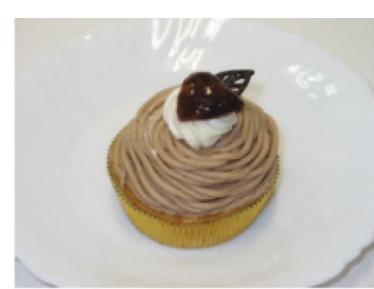

刺激 C モンブラン

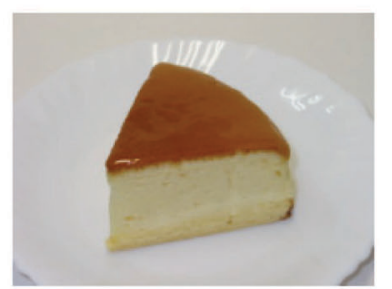

刺激 $\mathrm{G}$ チーズケーキ

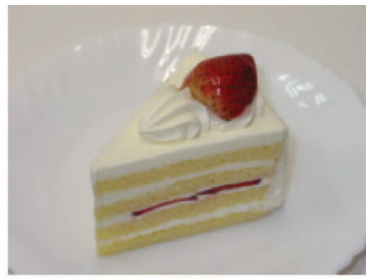

刺激 D 苜のショートケーキ

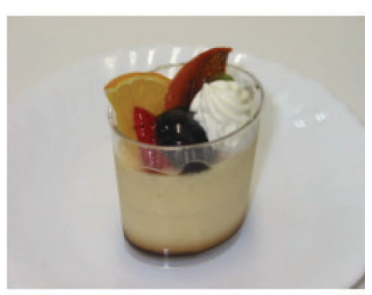

刺激 $\mathrm{H}$ プリンアラモード 


\section{表 1 印象項目の形容詞対}

\begin{tabular}{|c|c|c|c|}
\hline 順序 ${ }^{\mathrm{a}}$ & \multicolumn{2}{|c|}{ 形容詞対 ${ }^{b}$} & 相関係数 ${ }^{\mathrm{c}}$ \\
\hline 1 & 柔らかい & 硬い & 0.264 \\
\hline 2 & 美しい & 醜い & 0.495 \\
\hline 3 & あつい & 冷たい & 0.191 \\
\hline 4 & 複雑な & 単純な & 0.098 \\
\hline 5 & 甘い & 辛い & 0.254 \\
\hline 6 & 重い & 軽い & 0.122 \\
\hline 7 & 好き & 嫌い & 0.829 \\
\hline 8 & 繊細な & 大まかな & 0.261 \\
\hline 9 & 暗い & 明るい & 0.347 \\
\hline 10 & 食べたい & 食べたくない & 0.803 \\
\hline 11 & くすんだ & つややかな & 0.274 \\
\hline 12 & 洗練された & 粗野な & 0.370 \\
\hline 13 & おいしい & まずい & - \\
\hline 14 & やさしい & きつい & 0.516 \\
\hline 15 & 安っぽい & 高級な & 0.243 \\
\hline 16 & さっぱりした & しっこい & 0.218 \\
\hline 17 & 上品な & 下品な & 0.399 \\
\hline 18 & かわいた & しっとり & 0.196 \\
\hline 19 & 鮮やかな & 地味な & 0.300 \\
\hline
\end{tabular}

a 順序はアンケート用紙の回答順. ${ }^{\mathrm{b}}$ 太字で記載した形容詞の 方が高得点となるよう得点化. ${ }^{\mathrm{c}}$ 相関係数は「おいしい」との ケーキ毎の相関係数の絶対值平均. 0.200 以上の相関係数は 太字.

表 2 甘味嗜好検出項目

\begin{tabular}{clc}
\hline \hline 順序a $^{\mathrm{a}}$ & \multicolumn{1}{c}{ 質問項目 } & 相関係数 \\
\hline 1 & ケーキは子は好きですか & $\mathbf{0 . 3 0 8}$ \\
2 & チョコは好きですか & $\mathbf{0 . 2 1 7}$ \\
3 & 果物は好きですか & 0.158 \\
4 & チーズは好きですか & $\mathbf{0 . 2 3 2}$ \\
5 & 生クリームは好きですか & $\mathbf{0 . 2 6 0}$ \\
6 & 甘いすのは好きですか & $\mathbf{0 . 3 0 6}$
\end{tabular}

${ }^{\mathrm{a}}$ 順序はアンケート用紙の記載順。 ${ }^{\mathrm{b}}$ 相関係数は「扝 いしい」とのケーキ毎の相関係数の絶対值平均. 0.200 以上の相関係数は太字.

価), 甘味嗜好検出項目の項目に回答させた。 甘味嗜好検出 項目は表 2 の 6 項目で, 印象項目之同様に 7 件法で回答さ せた。

\section{4. 分析ソフトゥェア}

結果の分析に打いて，因子分析はSPSS13.0J（エス・ ピー・エス・エス株式会社)，共分散構造分析は AMOS5.0 （エス・ピー・エス・エス株式会社）を用いた。

\section{実験結果および考察}

\section{1. データの統合ならびに取捨選択}

印象項目の回答に抜けのあるあのを外した有効回答数は 計 226 であった（少人数実施が 43 , 大人数実施が 95 と 88). 有効回答者 226 名のうち男性は 165 名, 女性は 61 名であっ
た。また，年齢は平均 20.3 歳, 標準偏差は 2.0 歳であった. まず，各パネルの回答について，各形容詞対において， ケーキを見たときの評価として肯定的な形容詞（表 1 の形 容詞対のうち太字で記載）の方が数值が大きくなるよう に，7段階評価をそのまま得点化した。.以下の表記では，肯 定的な形容詞のみで形容詞対を表記する。

共分散構造分析を実施するためには，最低 200 程度のサ ンプルが必要であるといわれており, 各グループのデー夕 を統合できるかどうか検討した。最初に，大人数で実施し た回答の 2 組分について，ケーキ種 $\times$ 印象項目で両グルー プの平均值の比較をおこなったところ，どこにも 1 以上の 差はなかったため，両デー夕を統合した，次に，この統合 データと少人数実施データと同様の比較をしたところ，1

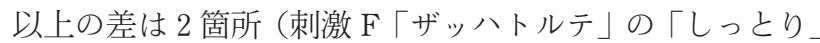
の項目で差 1.028 , 刺激 G「チーズケーキ」の「明るい」の 項目で差 1.106）でしかみられなかったので，両データで大 きな開きはないむのとして統合した。このようにして統合 した全データに関して, 各印象項目について天井効果やフ ロア効果がないか調べたところ，見つからなかった。

おいしそうという感情との関係を検討することが目的で あるため,これと関係する「おいしい」の項目と他の印象項 目ならびに甘味嗜好検出項目の相関係数をケーキ毎に求 め,これの絶対值をとり平均值を出した，そして，この值が 0.200 以上の項目を以下の分析で用いることとした（表 1 および表 2 の相関係数が太字の項目)。その結果，おいしい を含め 20 項目（印象項目 15，甘味嗜好検出項目 5) が選択 された。なお，表に含まれていない空腹具合は,「おいしい との相関係数が 0.124 と低かったので選択されなかった。

\section{2. 因子分析}

選択した項目を使い，最尤法による探索的因子分析をお こなった，スクリー・プロットの急激な変化点に基づく基 準では 3 因子が，固有值 1 以上を採用するカイザー・ガッ トマン基準では 4 因子が抽出された。プロマックス回転の 結果得られた因子パターンを表 3 と表 4 に示す。各因子に おいて 0.400 以上の值を持つ項目をその因子を構成する項 目と考えた。どの因子とあ 0.400 以下の值しか持たない項 目は排除した。

スクリー・プロット変化による基準の第 1 因子はカイ ザー・ガットマン基準の第 1 因子と同じであり，前者の第 3 因子は後者の第 2 因子と同じであった。前者の第 2 因子 は後者では第 3 ，第 4 因子に分かれた。

スクリー・プロット変化による基準の場合，第 1 因子は 評価，第 2 因子は色彩印象，第 3 因子は形態（造作）印象 に関係する項目であると考えられた。一方，カイザー・ ガットマン基準の場合，第 1 因子は評価，第 2 因子は形態 （造作）印象，第 3 因子は色彩印象，第 4 因子は複合印象に 関係する項目であると考えた。 


\section{3. 共分散構造分析}

(1) 初期モデル

因子分析により抽出した因子を参考に，図 2 に示すよう な共分散構造分析の初期モデルを作成し検討した。初期モ デル作成に当たって，潜在変数（図 2 の因子 $\mathrm{X}$ と記載され

表 3 スクリー・プロット変化状況より 3 因子を抽出したとき の因子パターン

\begin{tabular}{crrr}
\hline \hline 印象項目 & 第 1 因子 & 第 2 因子 & 第 3 因子 \\
\hline 好き & $\mathbf{0 . 9 7 8}$ & -0.054 & -0.033 \\
食べたい & $\mathbf{0 . 9 2 1}$ & -0.060 & 0.041 \\
おいしい & $\mathbf{0 . 8 7 7}$ & 0.025 & 0.025 \\
明るい & -0.074 & $\mathbf{0 . 9 2 1}$ & -0.093 \\
つややかな & -0.087 & $\mathbf{0 . 7 3 0}$ & 0.002 \\
柔らかい & 0.062 & $\mathbf{0 . 5 8 6}$ & -0.158 \\
鮮やかな & -0.150 & $\mathbf{0 . 5 6 1}$ & 0.284 \\
やさしい & 0.355 & $\mathbf{0 . 5 1 8}$ & -0.135 \\
美しい & 0.187 & $\mathbf{0 . 4 9 6}$ & 0.280 \\
高級な & -0.026 & -0.277 & $\mathbf{0 . 7 8 6}$ \\
繊細な & -0.079 & 0.047 & $\mathbf{0 . 6 8 5}$ \\
洗練された & 0.036 & 0.151 & $\mathbf{0 . 6 4 8}$ \\
上品な & 0.187 & 0.013 & $\mathbf{0 . 5 4 6}$ \\
\hline 回転後の因子 & 3.630 & 3.674 & 3.003 \\
負荷量平方和 & & &
\end{tabular}

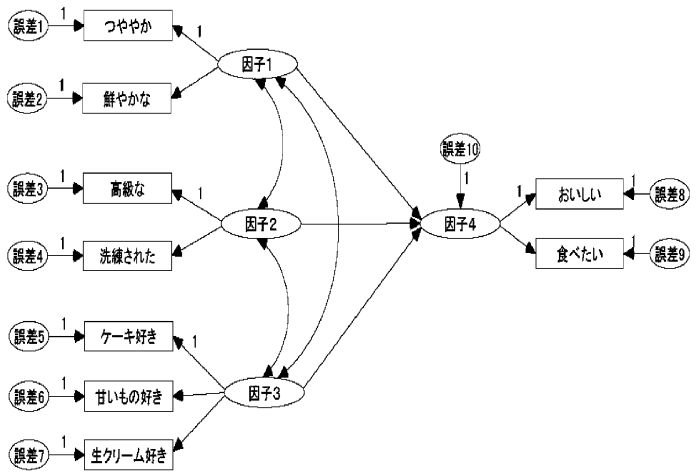

(a) 4 因子モデル

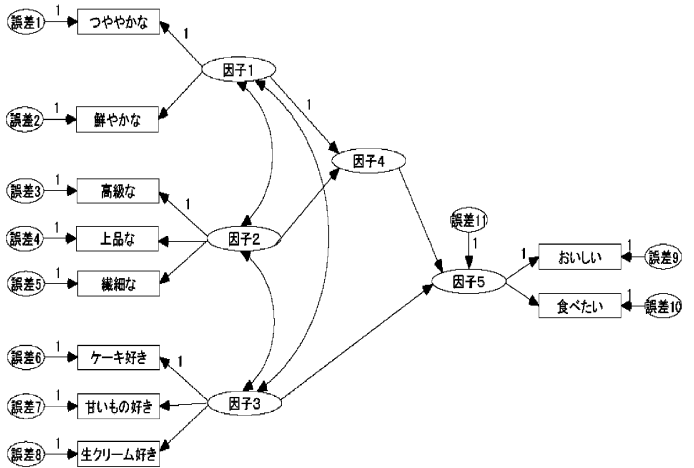

(c) 5 因子モデル 2
た楕円枠）として，因子分析により抽出した各因子と見る 人の内部要因である甘味嗜好を中心に考えた。因子分析に より抽出した各因子の潜在变数に関係する観測变数（図 2 の四角枠）は，因子分析の結果において各因子を構成する 印象項目とした。甘味嗜好の潜在変数に関係する観測变数

表 4 カイザー・ガットマン基準により 4 因子を抽出したとき の因子パターン

\begin{tabular}{crrrr}
\hline \hline 印象項目 & 第 1 因子 & 第 2 因子 & 第 3 因子 & 第 4 因子 \\
\hline 好き & $\mathbf{0 . 9 6 9}$ & -0.057 & 0.001 & -0.008 \\
食べたい & $\mathbf{0 . 9 3 1}$ & 0.002 & 0.028 & -0.047 \\
おいしい & $\mathbf{0 . 8 2 7}$ & 0.041 & -0.002 & 0.098 \\
高級な & 0.043 & $\mathbf{0 . 7 1 0}$ & -0.017 & -0.301 \\
繊細な & -0.084 & $\mathbf{0 . 6 5 6}$ & 0.089 & -0.005 \\
洗練された & -0.004 & $\mathbf{0 . 6 5 6}$ & 0.109 & 0.102 \\
上品な & 0.039 & $\mathbf{0 . 6 4 6}$ & -0.148 & 0.251 \\
鮮やかな & 0.040 & 0.164 & $\mathbf{0 . 7 5 5}$ & -0.188 \\
明るい & -0.009 & -0.076 & $\mathbf{0 . 7 1 5}$ & 0.243 \\
つややかな & 0.006 & -0.034 & $\mathbf{0 . 6 7 9}$ & 0.099 \\
やさしい & 0.086 & 0.067 & -0.005 & $\mathbf{0 . 7 4 6}$ \\
柔らかい & -0.072 & -0.028 & 0.171 & $\mathbf{0 . 5 1 0}$ \\
さっぱりした & 0.043 & -0.057 & -0.035 & $\mathbf{0 . 4 4 8}$ \\
\hline 回転後の因子 & 3.360 & 2.653 & 2.714 & 2.804 \\
鿓荷量平方和 & & & & \\
\hline
\end{tabular}

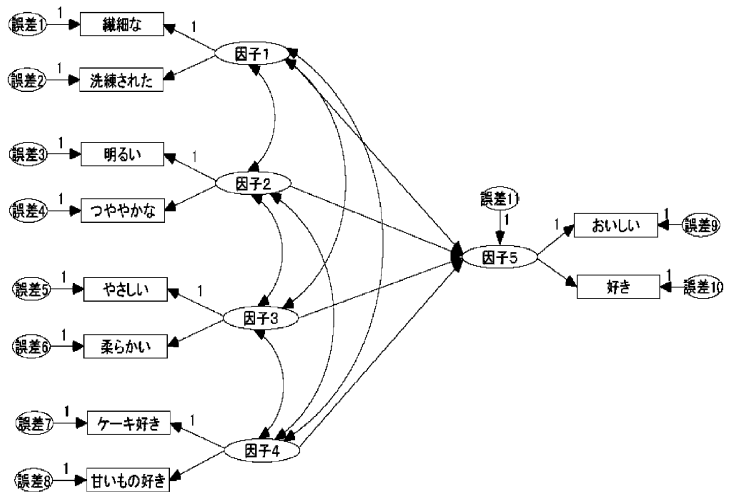

（b） 5 因子モデル 1

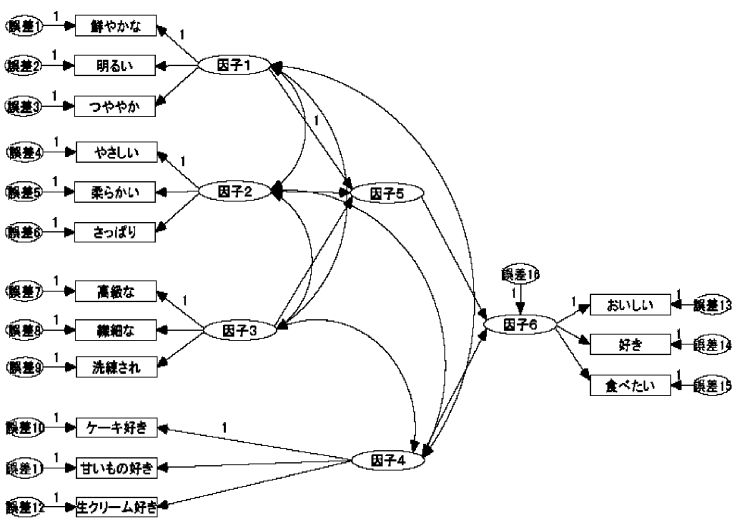

（d） 6 因子モデル

図 2 初期モデル 


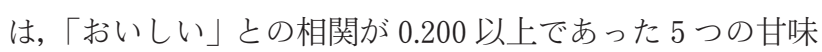
嗜好検出項目とした. また, 各潜在变数は $2 \sim 3$ の観測变数 を有することとした，このとき，最終的な評価に係る潜在 因子と関係する観測変数の一方は「おいしい」に固定した。

i ） 4 因子モデル（困 2a）

スクリー・プロット変化による基準に基づくあので，甘 味嗜好 (図 $2 \mathrm{a}$ の因子 3 : 甘味嗜好検出項目が相当), 色彩 印象 (図 $2 \mathrm{a}$ の因子 1 : 表 3 の第 2 因子が相当), 形態印象 (図 $2 \mathrm{a}$ の因子 2 : 表 3 の第 3 因子が相当), 評価（図 $2 \mathrm{a} の$ 因子 4 : 表 3 の第 1 因子が相当）に関係する潜在变数を仮 定した。前 3 者の間に共分散を仮定し, それぞれが評価に 影響を及ぼすと仮定した。

ii） 5 因子モデル 1 (図 2b)

カイザー・ガットマン基準によるあので，甘味嗜好（図2 $\mathrm{b}$ の因子 4: 甘味嗜好検出項目が相当), 形態印象 (図 $2 \mathrm{~b} の$ 因子 1 : 表 4 の第 2 因子が相当), 色彩印象 (図 $2 \mathrm{~b}$ の因子 2 : 表 4 の第 3 因子が相当), 複合印象 (図 $2 \mathrm{~b}$ の因子 $3:$ 表 4 の第 4 因子が相当), 評価(図 $2 \mathrm{~b}$ の因子 5 : 表 4 の第 1 因 子が相当）に関する潜在変数を仮定した。 前 4 者の間に共 分散を仮定し，それぞれが評価に影響を及ぼすと仮定した。

iii） 5 因子モデル 2 (図 2c)

4 因子モデルを拡張したあので, 色彩印象（図 2c の因子 1 : 表 3 の第 2 因子が相当) と形態印象（図 $2 \mathrm{c}$ の因子 2 : 表 3 の第 3 因子が相当）に関する潜在变数をまとめる潜在変 数（全体印象：図 2c の因子 4）を介在させたモデルであ る. 制約条件を満たすため, 全体印象の因子には誤差項を 入れなかった，評価因子で誤差項を考慮しているため，こ ちらに含まれると考えた。

iv） 6 因子モデル（図 2d）

5 因子モデル 1 を拡張したもので, 形態印象 (図 $2 \mathrm{~d}$ の因 子 1 : 表 4 の第 2 因子が相当), 色彩印象（図 $2 \mathrm{~d}$ の因子 2 : 表 4 の第 3 因子が相当), 複合印象（図 $2 \mathrm{~d}$ の因子 3 : 表 4 の第 4 因子が相当）に関する潜在変数をまとめる潜在変数 （全体印象：図 2d の因子 5）を介在させたモデルである。 5 因子モデル 2 と同様の考えの下に, 制約条件を満たすた め，全体印象の因子には誤差項を入れなかった。

\section{(2) 初期モデルの検討結果}

共分散構造分析には最尤法を用いた。各初期モデルにお いて，観測变数に関連する項目を順次投入し，ケーキ毎に 総当り的にモデルを調べた. $\chi^{2}$ 検定で 0.05 の基準を満たし モデルが観測デー夕に適合しているとされた組み合わせの 数は，表 5 のようになった。 すべてのケーキを説明できる モデルは存在しなかった。 6 因子モデルは最高 4 つのケー キしか説明できなかったため, 今後の検討から外した。

(3) 修正モデル

次に， 6 因子モデル以外の 3 つのモデルについて，各モ デルで最も適合したケーキの種類の多い観測变数の組み合 わせを使い, AMOS の修正指数の值を参考に，共分散を仮 定した部分を因果関係に置き換える作業をおこなった。以 下では，各ケーキにおいてモデルを適用した場合の $\chi^{2}$ 検定 の結果が 0.05 以上，GFI が 0.95 以上， RMSEA が 0.05 以 下の場合を適合度指数から判断される適合モデルとした。 さらにパス係数が負の值をとる場合も不適とした，各モデ ルの平均適合指数, 潜在変数の平均決定係数, 不適合で あったケーキの種類を表 6 に示した。

i ） 4 因子モデル（図 $3 a ）$

色彩印象变数, 形態印象変数, 甘味嗜好变数の 3 者間の 共分散関係を削除し，色彩印象变数と形態印象变数の間に 相互の因果関係を, 甘味嗜好変数から色彩印象への因果を おくことができた。しかしながら，このモデルでは，2つの 観測变数の組み合わせともに，適合度指数から判断される 説明可能なケーキの数が 5 つに減少した。

\section{表 $5 \quad \chi^{2}$ 検定で適合すると判断された観測変数の組み 合わせ数}

\begin{tabular}{ccccc}
\hline \hline & \multicolumn{4}{c}{ 適合したケーキの種類 } \\
\cline { 2 - 5 } 基本モデル & 8 & 7 & 6 & 5 \\
\hline 4 因子モデル & 0 & 2 & 19 & 93 \\
5 因子モデル 1 & 0 & 0 & 2 & 9 \\
5 因子モデル 2 & 0 & 0 & 11 & 63 \\
6 因子モデル & 0 & 0 & 0 & 0 \\
\hline
\end{tabular}

a適合したケーキの種類が 5 つ以上の場合のみを記載.

表 6 各モデルの適合度指数, 決定係数, 不適合だったケーキ種

\begin{tabular}{|c|c|c|c|c|c|c|c|c|}
\hline & $\chi^{2}$ のp值 & GFI & RMSEA & $\mathrm{AIC}$ & $\begin{array}{l}\text { 色彩印象 } \\
\text { 決定係数 }\end{array}$ & $\begin{array}{l}\text { 形態印象 } \\
\text { 決定係数 }\end{array}$ & 決定僄数 & $\begin{array}{l}\text { 不適合 } \\
\text { ケーキ }\end{array}$ \\
\hline \multicolumn{9}{|l|}{4 因子モデル } \\
\hline 組み合わせ 1 & 0.150 & 0.972 & 0.039 & 76.483 & 0.544 & 0.438 & 0.430 & $\mathrm{~B}, \mathrm{D}, \mathrm{F}$ \\
\hline 組み合わせ 2 & 0.185 & 0.974 & 0.034 & 75.455 & 0.592 & 0.406 & 0.520 & $\mathrm{~A}, \mathrm{D}, \mathrm{F}$ \\
\hline \multicolumn{9}{|l|}{5 因子モデル 1} \\
\hline 組み合わせ 1 & 0.164 & 0.970 & 0.035 & 91.022 & - & - & 0.666 & A, E, H \\
\hline 組み合わせ 2 & 0.175 & 0.971 & 0.034 & 90.056 & - & - & 0.672 & $\mathrm{D}, \mathrm{E}, \mathrm{F}$ \\
\hline \multicolumn{9}{|l|}{5 因子モデル 2} \\
\hline 組み合わせ 1 & 0.244 & 0.975 & 0.028 & 74.401 & 0.498 & 0.352 & 0.552 & $\mathrm{D}, \mathrm{F}$ \\
\hline
\end{tabular}




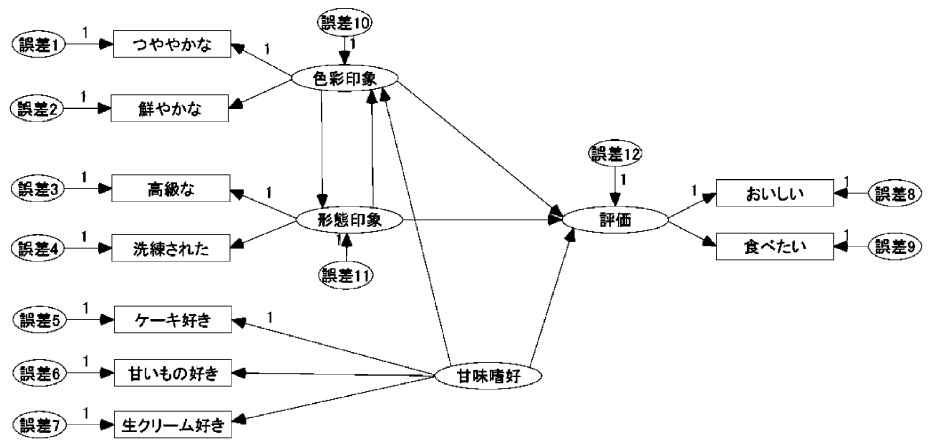

(a) 4 因子モデル

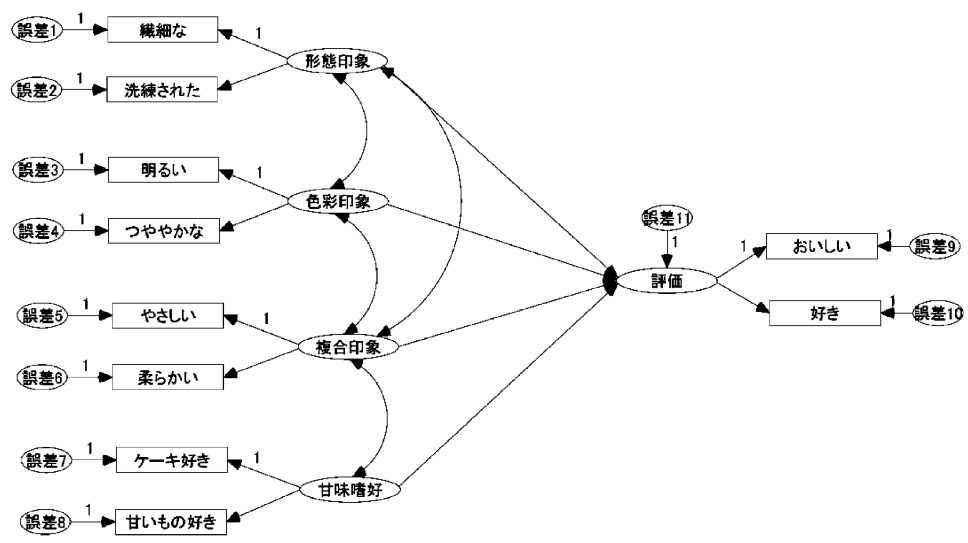

(b) 5 因子モデル 1

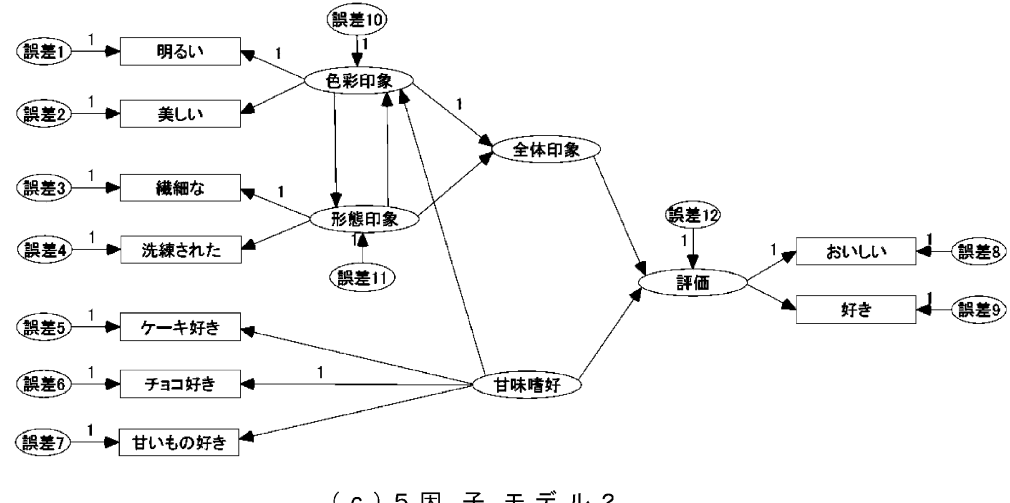

図 3 修正モデル

ii） 5 因子モデル 1（図 3b）

共分散関係を因果関係に置き換えることができなかっ た。ただし，置き換える作業の過程で，甘味啫好变数と形 態印象变数の間, 甘味嗜好变数之色彩印象变数の間の共分 散は削除可能であることがわかった。（共分散関係を残し たままであるが, ） 2 つの観測変数の組み合わせともに，適 合度指数から判断される説明可能なケーキの数が 5 つに減 少した。

iii） 5 因子モデル 2 (困 3c)

色彩印象变数, 形態印象变数, 甘味嗜好变数の 3 者間の共 分散関係を削除し，色彩印象变数と形態印象变数の間に相
互の因果関係を，甘味嗜好変数から色彩印象への因果をお くことができた。 11 種の観測变数の組み合わせのうち 1 つ において，適合度指数から判断される説明可能なケーキの 数が減少することがなかった（6 種のケーキに適合した）.

（4）最適モデルの決定

上記の分析の結果は, 適合したケーキの種類の多さ, $\mathrm{AIC}$ の低さ, 共に 5 因子モデル 2 を最適モデルであること を支持する屯のであった。このモデルは, 色彩印象変数の 観測变数として「明るい」「美しい」, 形態印象变数の観測 变数として「繊細な」「洗練された」，甘味嗜好变数の観測 変数として「ケーキが好き」「甘いものが好き」「チョコが 


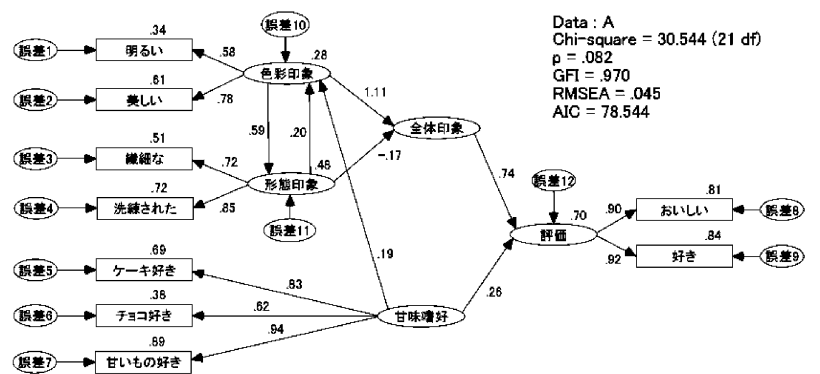

(a)刺激 A「果実の森」
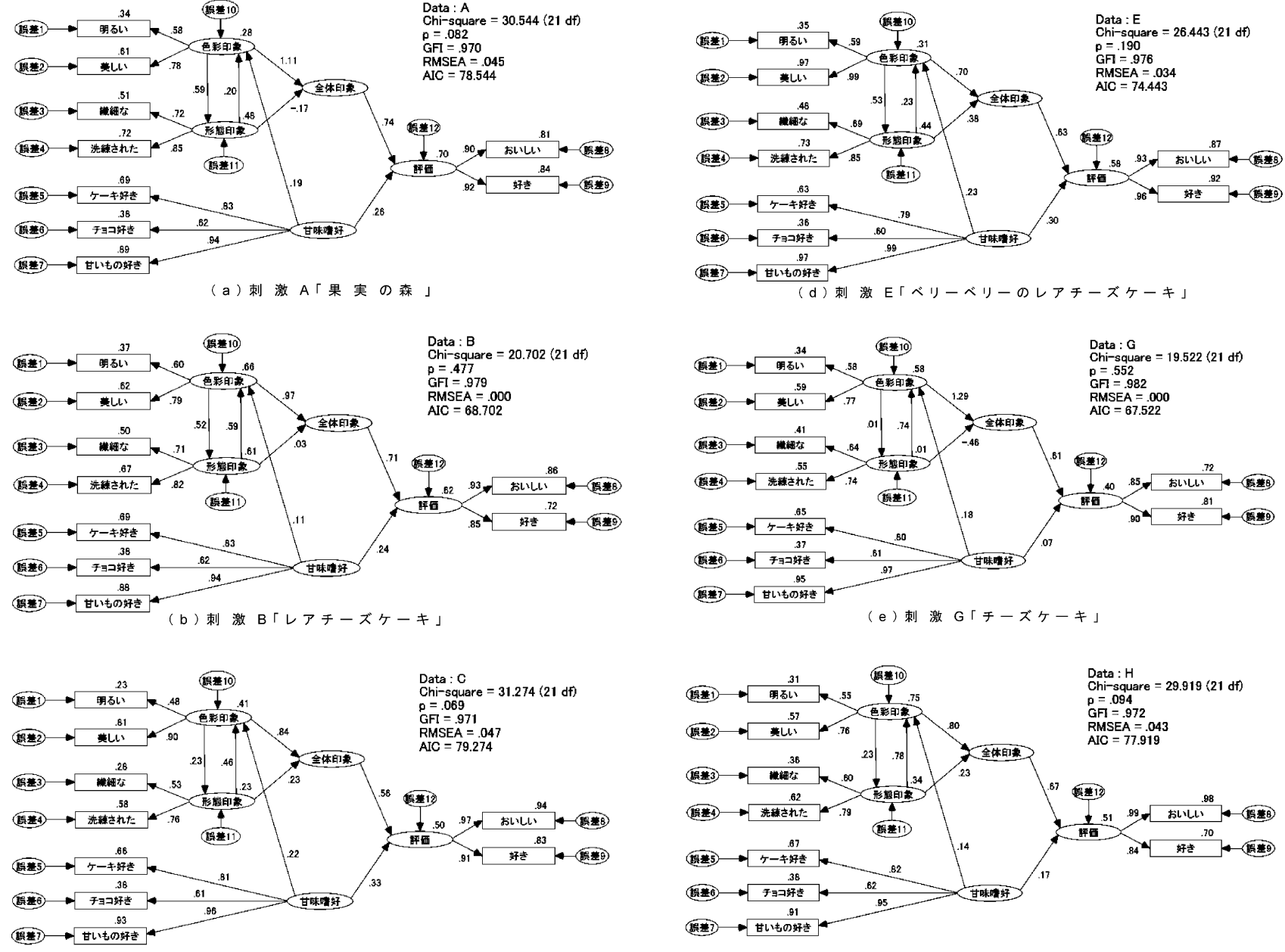

(c) 刺激 C「モンブラン」

(f) 刺激 H「プリンアラモード」

図 4 採択したモデルのケーキ適用例

好き」を持つあのであった，図 4 にこのモデルを使って適 合ケーキを説明するときの標準化推定值を記載したパス図 を示した。

見た目に「おいしい」が何によってどの程度決定される のかを検討するために，各潜在变数が「おいしい」に与え る標準化総合効果を求めた (表 7). 色彩印象变数がもっと あ効果が高く, 形態印象变数と甘味嗜好变数が同程度であ ることが示唆された。

すべてのケーキを説明できるモデルは見つからなかった が，8 種類のうち 6 種類のケーキを説明するモデルを見つ けることができた。 このモデルに従い，ケーキを見たとき に生じる内的プロセスを説明すると以下のようになる。

ケーキを見たとき，「明るい」「美しい」といった色に関 係する印象之「繊細な」「洗練された」といった形や造作に 関係する印象が別個に形成される。両者はお互いに影響を 及ぼし合っているが，両者からケーキ自体の全体印象が形 成される。全体印象と見る人の甘味に関する嗜好が合わ さって，そのケーキがおいしそうだとか好きといった感情 が生じる。
表 7 「おいしい」との標準化総合効果

\begin{tabular}{cccc}
\hline \hline ケーキ & 色彩印象 & 形態印象 & 甘味嗜好 \\
\hline $\mathrm{A}$ & 0.769 & 0.038 & 0.380 \\
$\mathrm{~B}$ & 0.940 & 0.571 & 0.331 \\
$\mathrm{C}$ & 0.545 & 0.378 & 0.432 \\
$\mathrm{E}$ & 0.609 & 0.368 & 0.415 \\
$\mathrm{G}$ & 0.669 & 0.256 & 0.178 \\
$\mathrm{H}$ & 0.683 & 0.687 & 0.264 \\
平均 & 0.703 & 0.383 & 0.333 \\
\hline
\end{tabular}

人の甘味に関する嗜好は色に関係する印象にむ影響を及 ぼすので，ケーキ自体の全体印象にも見る人の甘味に対す る嗜好が反映されることになる。したがって，ここで仮定 した全体印象は完全に客観的な印象ではなく，嗜好が多少 まじった印象ということになる。

各潜在変数が「おいしさ」に及ぼす標準化総合効果は色 彩印象变数が最も高かった。経験的に色はおいしさと関係 が深い重要な要因として考えられており7), 今回の結果は それを裏付けるものとなった。 
ただし，観測変数としては，「明るい」「美しい」が選択 されているので, 色相ではなく, 明度とより高次の感性が 関わっていると考えることができる. 一方, 形態変数や甘 味嗜好变数はほぼ同等の総合効果となった。 甘味嗜好变数 の効果が低かったのは，パネルができるだけ客観的に各 ケーキを評価しようとしたためではないかと思われる。

空腹状態についての項目は「おいしい」との相関が低く, 今回のモデルには入らなかった。しかし，日常的には，同 じ食品が空腹状態か満腹状態かによっておいしそうに見え たり，それほどでもなく見えたりする．同じパネルに空腹 状態のときと満腹状態のときの 2 回, アンケートをとるな どして再検討をする必要があろう.

\section{要約}

食品の見た目のおいしさについて検討するために，ケー キの写真を見た際に生じる印象について, SD 法によるア ンケート調査を実施した。その結果，3ないしは 4 因子を 抽出することができた. この結果を参考に，4 種類の初期 モデルを構築し，共分散構造分析を実施した。モデルを修 正しながら，ケーキ写真毎にアンケート調査データと適合 性を検討した。最も適合すると考えられたモデルは以下の あのであった.

ケーキ写真から色彩に関する印象と形態に関する印象が 生じる. 両者には相互に因果関係があり, 両者からケーキ 写真についての全体印象が生じる. 見る人の甘味に関する 嗜好は色彩に関する印象に影響を及ぼす。また, 甘味に関す る嗜好とケーキ写真についての全体印象から, ケーキ写真
についての評価が定まり, 見た目のおいしさが決定される.

本研究の実施に当たり, 科学技術振興調整費・戦略的研 究拠点育成プログラム「ユーザーを基盤とした技術・感性 融合機構」の援助を受けた．本研究は，金子智範君（九州 大学工学部電気情報工学科) の卒業研究として筆者らが指 導をおこなったものである。また，デー夕の整理には研究 室学生諸君の協力を得た。

\section{文献}

1) Imram, N., The role of visual cues in consumer perception and acceptance of a food product. Nutrition and Food Science, 99 (5), 224-228 (1999).

2) Jaros, D., Rohm, H. and Strobl, M., Appearance properties-A significant contribution to sensory food quality-. LWT-Food Science and Technology, 44 (4), 320326 (2000).

3）真柳麻誉美, 鈴木督久, 古我可一, バニラカップアイスのお いしさモデル一共分散構造分析による検討, 女子栄養大学 紀要, 29, 61-71 (1998).

4）相良泰行，池田岳郎，おいしさのモデリングによる品質設 計, 「おいしさをさぐる食品感性工学」, 相良泰行監修, (化 学工業日報社, 東京), pp. 213-245 (2004).

5）豊田秀樹,「共分散構造分析〔入門編〕」, (朝倉書店, 東京), (1998).

6）山本嘉一郎，共分散構造分析とその適用，「Amos による共 分散構造分析之解析事例」, 第 2 版, 山本嘉一郎, 小野寺孝 義編著, (ナカニシャ出版, 京都), pp. 1-22（2002）.

7）片山 脩 - 田島 眞, 「食品之色」, (光琳, 東京), (2005). (平成 18 年 3 月 16 日受付, 平成 18 年 10 月 3 日受理) 